\title{
Turizmusnak látszó kiskereskedelem: az utazással párosuló termékbemutatók anatómiája a reklámcédulák elemzése alapján
}

\author{
Retail disguised as tourism: \\ the anatomy of sales show trips based on the analysis of \\ promotional leaflets
}

\author{
MICHALKÓ GÁBOR, RÁTZ TAMARA, RÉGI TAMÁS
}

MICHALKÓ Gábor: tudományos tanácsadó, MTA CSFK Földrajztudományi Intézet, Budapest; michalko.gabor@csfk.mta.hu

RÁTZ Tamara: igazgató, Kodolányi János Főiskola, Gazdaságtudományi Képzési Központ, Székesfehérvár; tratz@kodolanyi.hu

RÉGI Tamás: egyetemi adjunktus, Keimyung University, Sociology Department, Daegu, Dél-Korea; regitamas@hotmail.com

KULCSSZAVAK: bevásárlóturizmus, kiskereskedelem, termékbemutató, utazás, tartalomelemzés

ABSZTRAKT: A magyar társadalom a nemzetközi és a belföldi bevásárlóturizmusban egyaránt érintett. A határainkon belül zajló és az azokon túlra irányuló egynapos forgalomban a vásárlás hosszú ideje vezető utazási motiváció. A kiskereskedelmi szféra azonban a diszkontáruházak, a hipermarketek és a bevásárlóközpontok költésre csábító világán kívüli értékesítési formákkal is igyekszik az utazással párosuló keresletet élénkíteni és szélesíteni. A tv-shopok stílusában zajló, leginkább vendéglátó-ipari egységekben vagy különféle közösségi terekben lebonyolított termékbemutató a számos nem bolti kiskereskedelmi értékesítési eljárás egyike. A termékbemutatókat szervező cégek a forgalom növelése érdekében egynapos, belföldi vagy a határhoz közel fekvő településeket megcélzó utazással házasították az alapvetően adásvételre fókuszáló rendezvényt. A tanulmány a postaládákba dobott reklámcédulák tartalomelemzésével az utazással párosuló termékbemutatók világát tárja fel. A munka 2006 és 2011 között gyüjtött 339 cédula vizsgálatával kívánja igazolni, hogy a vonzó utazási ajánlatként feltüntetett, főleg az idősebb korosztályt érintő kirándulások valójában a termékértékesítést ösztönző promóciós eszközök, amelyek Magyarország láthatatlan turizmusának letéteményesei.

Gábor MICHALKÓ: scientific advisor, Geographical Institute, Research Centre for Astronomy and Earth Sciences, Hungarian Academy of Sciences, Budapest; michalko.gabor@csfk.mta.hu Tamara RÁTZ: director, Centre for Business Studies, Kodolányi János University of Applied sciences, Székesfehérvár; tratz@kodolanyi.hu

Tamás RÉGI: assistant professor, Sociology Department, Keimyung University, Daegu, South Korea; regitamas@hotmail.com

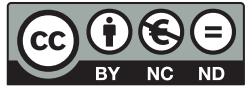


KEYWORDS: shopping tourism, retail, sales show, travel, content analysis

\begin{abstract}
The Hungarian society is involved in shopping tourism both at international and national levels. For domestic and cross-border day trips, shopping has been a leading travel motivation for many years. In addition to the seductive shopping environments of discount stores, hypermarkets and shopping malls, the retail sector aims to stimulate and widen travelrelated demand by introducing alternative sales methods. One such method, outside the domain of retail outlets, is the TV-shop-style "sales show" or "product demonstration" that usually takes place in restaurants or in community spaces. In order to increase the number of participants, the companies organising product-demonstration shows usually combine these directly salesoriented events with domestic or cross-border day trips. Using the method of content analysis of promotional flyers distributed through letterboxes, this study explores the world of sales show trips. The analysis of 339 leaflets collected between 2006 and 2011 aims to demonstrate that these trips - presented as attractive travel opportunities and targeting mainly the senior-citizen segment - are, in fact, methods of sales promotion that are also included in the notion of "invisible tourism" in Hungary.

Our research has proved the hypothesis that in these trips, the "travel function" is secondary, merely meant to create the illusion of escaping one's mundane life and to move participants to an unfamiliar space where they are more likely to make hasty, less deliberated decisions, culminating, eventually, in purchasing the products on show. However, despite the fact that the visited destinations mainly act as stages for the process of product selling, and travel may be considered a "pseudo-tourist experience", these trips do help participants learn more about the Carpathian basin, and increase the turnover of domestic tourist and leisure companies. It should also be noted that, in addition to their economic role, these trips fulfil a specific social tourism mission, too, providing some travel and community experience for their least wealthy, usually retired participants.
\end{abstract}

\title{
Bevezetés
}

Az elmúlt évtizedben a magyarországi postaládák funkciója alaposan megváltozott. Az internetalapú ügyintézés és az elektronikus levelezés térhódításának köszönhetően a hagyományos postai küldemények száma megcsappant, helyüket a reklámújságok és a szórólapok váltották fel. A lakosság, amikor kinyitja a postaládáját, leginkább a hiper- és szupermarketek aktuális akcióiról tájékoztató brosúrákkal szembesül. Egyesek (pl. az akcióvadászok) örömmel, mások (pl. a környezetvédők) kénytelen-kelletlen ürítik levélszekrényükből az efféle reklámküldeményeket. A kiskereskedelmi szféra azonban nemcsak a fogyasztás új katedrálisaiba (Sikos T., Hoffmann-né 2004), az árufétis (Marx 1955) szentélyeibe invitálja a lakosságot, hanem más értékesítési formákat is felajánl a postaládákba gyömöszölt szórólapokon keresztül. Ezek közül az utazással párosuló termékbemutatókra csábító színes cetlik a legfeltűnőbbek, amelyek gyakran a postaládák közelében álló kukák mélyén vagy a kapualjakban szanaszét szórva végzik. A lakosság általános averziója ellenére jó néhányan vannak olyanok, akiknek sikerül az érdeklődését felkelteni a tv-shopok stílusában zajló előadásokra épülő utazási ajánlatokkal. Különösen az idősebbek számára jelent a szembeötlően olcsó, garantált ajándékokat kínáló autóbuszos kirándulás vásárlási és kikapcsolódási lehetőséget. 
Az utazással párosuló termékbemutatók mindeddig elkerülték a kiskereskedelem és a turizmus szimbiózisával foglalkozó kutatók figyelmét, elvétve találkozhatunk a témával foglalkozó értekezéssel (Hunyadi 2011). Ennek hátterében feltehetően a termékértékesítés és a szabadidős utazás határmezsgyéjén álló jelenség rejtőzködő mivolta húzódik. Egyrészt sem a belkereskedelemre, sem a turizmusra vonatkozó hivatalos statisztika nem tartalmaz ilyen típusú utazásokkal kapcsolatos adatokat. Másrészt a termékbemutatókat szervező cégek többsége meglehetősen kérészéletű, hamar kikerülnek az őket adatközlésre kötelező, a tevékenységüket ellenőrző hatóságok látóköréből. Harmadrészt a programok lebonyolítói kínosan ügyelnek arra, hogy a „kívülállóknak” a lehető legkisebb rálátásuk legyen az általuk generált folyamatokra. Tekintettel arra, hogy az érintett vállalkozások a tudományos kutatást célzó megkeresések elől elzárkóznak, adatokat nem szolgáltatnak, interjút nem adnak, az utazók között lebonyolított primer vizsgálatokat nem engedélyeznek, igencsak szűkre szabott a mozgástér a jelenség sajátosságainak feltárására.

Az utazással párosuló termékbemutatók megismerésének korlátozottságán jelentősen enyhít a szórólapok információdömpingje. A tartalomelemzés módszerével (Stepchenkova 2012) számos, a kiskereskedelem és a turizmus szimbiózisa szempontjából releváns tudnivaló kiolvasható az érintett cégek ajánlataiból. A tanulmány legfontosabb célkitűzése, hogy a kutatás során összegyüjtött 339 cédula elemzésével árnyaltabb képet alkothassunk az utazással párosuló termékbemutatók világáról. Ezzel egyidejűleg azokat a tényezőket kívánjuk feltárni, amelyek közelebb visznek kiinduló hipotézisünk megválaszolásához: az érintett cégek kínálatában az utazás funkciója csupán a környezetváltozás, a mindennapok világából való kiszakadás illúziójának felkeltése, amely meggondolatlanabb döntésekre, végső soron a felkínált termékek megvásárlására ösztönzi a résztvevőket.

\section{Elméleti háttér}

A kiskereskedelem és a turizmus kapcsolatának problematikája az utóbbi évtizedekben folyamatosan foglalkoztatta a tudomány képviselőit. A kutatások többsége a jelenség legeklatánsabb megnyilvánulási formájára, a határ menti bevásárlóturizmusra koncentrált, egyrészt a szomszédos országok állampolgárainak turisztikai magatartását, másrészt az érintett települések kiskereskedelmi kínálatának sajátos vonásait elemezte (Di Matteo, Di Matteo 1996; Michalkó 2000; Michalkó, Colombino, Minca 2005; Michalkó, Timothy 2001; Timothy 1999; Timothy, Butler 1995; Tömöri 2011). Számos esetben azonban arra is rámutattak a kutatók, hogy a bevásárlóturizmus egymástól távolabb fekvő országok viszonylatában is prosperál (Hobson 1996). A kiskereskedelem-orientált turizmusnak az adott városok fejlődésére, funkciójára, társadalmi-gazdasági életére, imázsá- 
ra gyakorolt hatásának vizsgálata sem kerülte el a kutatók figyelmét (Heung, Qu 1998; Michalkó, Váradi 2004). A bevásárlóturizmus különleges szuprastruktúrája (pl. repülőterek, kompok vámmentes üzletei) is több értekezésnek képezte már tárgyát (Freathy, O'Connell 1999). A kiskereskedelem és a turizmus közötti kapcsolatok vizsgálatának igen tekintélyes eredményekkel rendelkező területe a szuveníripar, a kutatások a piac működésének elemzésén túlmenően a szuvenírek kultúrantropológiai megközelítésű sajátosságaira, valamint a termék és a hely szimbiózisára is kitérnek (Anderson, Littrel 1995; Gordon 1986; Littrel 1994; Philips, Steiner 1999; Shenhav-Keller 1993). Végül, de nem utolsósorban nem szabad megfeledkezni az alapvetően elméleti megközelítéseket közreadó munkákról sem, amelyek jelentős mértékben elősegítették a jelenség tudományos igényü értelmezését és a megértést segítő modellek megalkotását (JansenVerbeke 1991; Murphy, Benckendorff, Moscardo, Pearce 2012; Timothy 2005).

Az utazással párosuló árubemutatók problémaköréhez azok a vizsgálatok állnak legközelebb, amelyek fókuszában különféle kézműves műhelyek (pl. keramikus), mezőgazdasági (pl. borpince) és élelmiszeripari (pl. szeszfőzde) üzemek, gyárak (pl. autógyár) turizmusban betöltött szerepének az elemzése áll (Coles 2004; Littrel 1990). A kutatások rámutatnak arra, hogy egy utazási program részét képező üzemlátogatást követően a turisták szívesen vásárolnak az adott cég mintaboltjában. Ezen attrakciók felkeresése tehát a turisztikai élményen túlmenően, illetve arra építve szolgálja az adott termék eladásának ösztönzését, vagyis a közvetlen kiskereskedelmi célokat. Abból a felismerésből kiindulva, hogy a turistáknak a vásárlás iránti attitűdje szoros kapcsolatban van az általuk felkeresett desztináció atmoszférájával (Murphy, Moscardo, Benckendorff, Pearce 2011; Wong, Wan 2013), a különböző termékeket előállító üzemek is a legkülönbözőbb eszközökkel igyekszenek élénkíteni látogatóik vásárlási hajlandóságát és erősíteni az adott márkához kötődő keresletet (McBoyle 1996; Toops 1993).

A kiskereskedelemmel foglalkozó szakirodalom rámutat arra, hogy az árucikkek iránti bizalom tudatos kialakításában az emberi tényező alapvető fontosságú, a hiteles informátortól származó meggyőző érvek előbb-utóbb elvezetnek a vásárláshoz (Darden, Lennon, Darden 1978). A hiper- és szupermarketekben, bevásárlóközpontokban tartott prezentációk (árubemutatók) is a kommunikációban rejlő lehetőségek kiaknázására építenek (Nordfalt, Lange 2013; Sands, Oppewal, Beverland 2009). A korszerü értékesítési technológiák tárházában a televíziónak kezdetektől fogva meghatározó szerepe van. Egy képernyőre kerülő meggyőző prezentáció felkelti a nézők érdeklődését az adott termék iránt és fokozza vásárlási hajlandóságukat (Jenssen 1966; Skumanich, Kintsfather 1998; Walsh, Gwinner 2009). A tv-shopok prezentációi ugyan nélkülözik az interaktivitást, a sármos értékesítő mégis képes a személyes megszólítottság érzését kialakítani az otthon ülő tv-nézőben. A tv-shopok kínálatára némileg fogékony személyek ezt a paraszociális interakciót úgy értelmezik, hogy az értékesíton kifejezetten a néző kedvében szeretne járni, szinte hozzá beszél, őt szórakoztatja (az illető - a sok ismétlésnek köszönhetően - a néző zsánerévé, már-már csa- 
ládtaggá válik). Mindezért cserébe a néző a vásárlásról szóló, a racionalitást legtöbbször nélkülöző döntésével jutalmazza az értékesítőt.

A szakirodalom feldolgozása alapján elmondható, hogy a bevásárlóturizmus tradicionális értelmezési tartományába azok az utazások tartoznak, amelyek elsődleges motivációja a vásárlás, az utazók legalább költésük 50\%-át fordítják javak beszerzésére. Az árubemutatóval párosuló utazások sajátos helyet foglalnak el a bevásárlóturizmus fogalmi rendszerében, mivel a jelenségről nem állapítható meg egyértelmüen, hogy kiskereskedelem vagy turizmus. Elméleti megközelítésből kereskedelmi tevékenységről beszélhetünk, az utazás az adott termék értékesítését segítő promóció része. Ugyanakkor a körülmények (utazásszervező közreműködése, klasszikus autóbuszos kirándulás, vendéglátó-ipari egységben történő étkezés) és a programban résztvevők magatartása alapján nem hagyhatjuk figyelmen kívül a jelenség turizmushoz való kötődését sem.

\section{A vizsgálat módszere}

Az utazással párosuló termékbemutatók vizsgálatánál abból indultunk ki, hogy e szolgáltatásról nincs hivatalos statisztikai adatgyüjtés. Nem tudható, pontosan hány cég foglalkozik ilyen programok szervezésével, mennyi az ilyen utazások száma, azokon hány fó vesz részt stb. Mivel a szolgáltatás az esetek többségében egynapos belföldi kirándulásként jelenik meg, annak volumene rejtve marad a regisztrálásra hivatott szervezetek előtt, és ez a láthatatlanság egyben minden érintett vállalkozás érdeke. A hatóságok az utazással párosuló termékbemutatókat fogyasztóvédelmi problémaként szemlélik, a bejelentéseket kivizsgálják, az eljárás eredményét közzéteszik (Nemzeti Fogyasztóvédelmi Hatóság 2011). Ezekből a jelentésekből azonban csak a visszaélések fogyasztóvédelmi kérdései körvonalazódnak, nem nyerhető teljes kép a müködés sajátosságairól. A szekunder források köréből egyes internetes fórumok (fn.hir24.hu 2012) vagy a téma iránt érdeklődő oknyomozó újságírók cikkei (Hajdú 2012; S. Ráduly 2001) is adalékul szolgálhatnak. Az utazással párosuló termékbemutatók kiskereskedelmi és turisztikai jellemvonásairól a tudomány normáinak megfelelő hiteles és érvényes tudás csak primer adatgyüjtésre alapozva hozható létre.

Mivel az utazásszervezéssel és a termékértékesítéssel foglalkozó cégek teljes mértékben elzárkóztak a kutatásban való együttműködéstől, az utazással párosuló termékbemutatók vizsgálatához két kézenfekvő primer forrás állt rendelkezésünkre. Az egyik a postaládákba bedobott, kirándulásokra invitáló reklámcédulákból kiolvasható információk, a másik az ilyen utazásokon részt vettek körében folytatott adatgyüjtés. A Magyarország láthatatlan turizmusa címü OTKA kutatási projekt keretében mindkét lehetőséget kihasználtuk: egyrészt tartalomelemzést végeztünk a rendelkezésünkre álló reklámcédula-gyűjteményen, másrészt interjúkat készítettünk a buszos kirándulásokon részt vett sze- 
mélyekkel. Ebben a tanulmányban a reklámcédulák tartalomelemzésének legfontosabb eredményeit mutatjuk be.

A tartalomelemzés a korszerü társadalomtudományi kutatások egyik kedvelt módszere (Babbie 1999). A vizsgálat szöveges vagy képi tartalmak előre megadott szempontrendszer szerinti feldolgozását és értékelését jelenti (Czirfusz 2010; Kun, Boros, Pál 2009; Zsom 2013). A turizmuskutatásban számtalan, elemzésre kiválóan alkalmas tartalom áll rendelkezésre, így például górcső alá vehetők a turizmusipar működésére vonatkozó jogszabályok, a turisztikai desztinációk fejlesztését előirányzó dokumentumok, a különböző szintű marketingtervek, az utazási irodák katalógusai, a szolgáltatók honlapjai, az utazással kapcsolatos magazinok, tévéműsorok stb. (Malloy, Fennell 1998; Nickerson 1995; Sirakaya-Turk, Uysal, Hammit, Vaske 2011).

Az utazással párosuló termékbemutatók vizsgálatához a 2006-2011 között Budapesten (XVI. kerület), Gyöngyösön és Debrecenben 3 postaládába bedobott rendkívül színes, információk tömkelegét tartalmazó reklámcédulák (jellemzően $20 \times 10 \mathrm{~cm}$ nagyságú, fekvő tájolású lapok) tartalomelemzését végeztük el. A 6 év alatt összegyüjtött, 339 (különböző időpontra szóló, különböző célterületre irányuló) utazást reklámozó cédula nem fedi le és nem is reprezentálja a teljes magyarországi piacot, ugyanakkor elemzésre, a kínálat legfontosabb sajátosságainak értékelésére alkalmas információkat hordoz. Minden egyes cédulát az előre meghatározott szempontok (időpont, célterület, szervező, célcsoport, reklámajándék, szabadidős program, szolgáltatások, ár) alapján vizsgáltunk meg, az eredményeket Excel-táblázatban rögzítettük, ahol lehetett, kódolást alkalmaztunk. Az adatbázist SPSS 8.0 szoftverrel dolgoztuk fel, az elemzés során egyszerü matematikai és statisztikai eljárásokat (gyakoriságszámítás, kereszttábla) alkalmaztunk. A szervezőkkel kapcsolatos információkat a hatályos cégjegyzékből gyüjtöttük össze.

\section{A termékbemutatós utazások társadalmi-gazdasági környezete}

Az utazással párosuló termékbemutatók történelmi kontextusba helyezve értelmezhetők. Az a generáció, amely elsődleges célközönségét képezi az ilyen típusú utazásoknak, 1990-et megelőzően két, a kereslet fenntartásához hozzájáruló tényezőhöz szocializálódott. Az egyik a hiánygazdaságból fakadó kényszer (Hankiss 1989; Kolosi 1984; Kornai 1994), azaz hogy a kiskereskedelmi szféra nem biztosított számukra megfelelő mennyiségü és minőségü árucikket (amelyekre a nyugatról beszivárgó áruházi katalógusok, filmélmények, elbeszélések alapján vágytak); ezek beszerzéséért külföldre (keletre és nyugatra egyaránt) kellett utazni, így a jelenleg hatvanas éveikben járók a szocializmus bevásárlóturizmusának működtetői voltak (Michalkó 2004). A másik, hogy a pártállami rendszer a társadalom jelentős részének biztosította a szociálturisztikai ellátásokat, amelyek emlékezetes vállalati, szakszervezeti autóbuszos kirándulásokban öltöttek testet. 
A rendszerváltozást megelőzően kevés lehetőség nyílott érték- és haszontermelő tulajdonná konzerválni az egyének jövedelmét, ezért a személyes fogyasztás jelentősége megnőtt, sokan kultusztárgyak és szimbolikus értékek beszerzése miatt indultak útnak (Dessewffy 1998; Wessely 2000). 1990 után a kiskereskedelem liberalizációjának köszönhetően valamelyest enyhült az árufétis, megjelentek Magyarországon a nemzetközi hiper- és szupermarketek, egymás után épültek a bevásárlóközpontok (Nagy 2000; Sikos T., Hoffmann-né 2004). Ugyanakkor az a korosztály, amely egykor vállalati, szakszervezeti kirándulásokon töltötte el a szabadidejét, lassan nyugdíjba vonult, életszínvonala visszaesett, a hétköznapok információáradatától távolabb, csendesebben élte mindennapjait. Internethez való hozzáférésük informatikai eszköztáruk és tudásuk elégtelensége miatt szűkös, de személygépkocsi hiányában a városközponttól távolabb fekvő hipermarketekbe és szakáruházakba sem jutnak el, így kevés fogalmuk van az aktuális árukínálatáról és az ár-érték arányról. Alapvetően ezt a korosztályt célozták meg az utazással párosuló termékbemutatókat szervező cégek, visszahozva számukra az egykori autóbuszos kirándulások nyújtotta társas kapcsolatok és a „világot látás” élményét. Mindehhez exkluzívnak tűnő árucikkeket kínáló, a nehezen beszerezhetőség és az egyéni megszólítottság látszatát keltő termékértékesítés párosul.

A magyarországi termékbemutatók története a rendszerváltozás időszakára vezethető vissza, amikor is a kiskereskedelem fokozatos liberalizációjának egyik vadhajtásaként a bolti forgalomba - leginkább prémium minőségük és magas áruk miatt - nem kerülő árucikkek (pl. kozmetikum, háztartási vegyi áru, konyhafelszerelés, takarítógép) értékesítésére a cégek otthonokban és közösségi terekben (művelődési házak, iskolák, éttermek stb.) szerveztek termékbemutatókat. A működőképesség fenntartására értékesítési hálózatok jöttek létre, amelyek az MLM (multi-level marketing) rendszerével ismerősökre és azok ismerősire építettek. Amikor már a "fél ország” Amway- ${ }^{1}$ és porszívóügynök volt, új értékesítési eljárást kellett alkalmazni, hogy az addigra már a kereskedelmi televíziók adásaiból is ismertté vált termékbemutatók iránti érdeklődést fenntartsák. Az 1990-es évek közepétől a Németországban „Kaffeefahrt” néven működő rendszer (pfiffige-senioren.de 2013) terjedt el Magyarországon, amely a termékbemutatók utazással való házasítására épített.

\section{A termékbemutatós utazások anatómiája}

\section{A szervezők}

Az utazással párosuló termékbemutató alapvetően két cég együttműködésének gyümölcse, az egyik az autóbuszos kirándulásért, a másik a termékbemutatóért felel, előfordulnak azonban olyan esetek is, amikor egyetlen cég áll az utas szá- 
mára komplex kínálatként megjelenített ajánlat hátterében. Az ilyen kirándulások az utazásszervezésre vonatkozó jogszabályok ${ }^{2}$ alapján komplex terméknek minősülnek, így elvileg csak utazásszervezői jogkörrel rendelkező cégek foglalkozhatnak termékbemutatós utak programjának összeállításával és lebonyolításával. A vizsgálatba vont reklámcédulák alapján azonban számos, e tanulmány keretei között csak érintőlegesen tárgyalt visszásság mutatkozik.

A cédulákon szereplő cégek nevét és azok postacímét vizsgálva feltűnik, hogy egyes esetekben ugyanazon cím alatt különböző cégnevekkel találkozhatunk (1. ábra). Például a 9200 Mosonmagyaróvár, Pf. 85 cím alatt 2007-ben Albatross Travel, 2008-ban Sonnenlicht SP Kft., 2010-ben Sun and Light Kft., 2011-ben Olcsó Kirándulás Kft. várta az érdeklődők jelentkezését. A szervező cégek dinamikus változása, alapítása és megszűnése a hivatalos cégjegyzékből is nyomon követhető. A cédulák alapján 38 különböző elnevezésű, termékbemutatós utazást kínáló vállalkozást azonosítottunk, amelyek közül - a cédulák számát tekintve - a legintenzívebb piaci jelenléttel az Albatross Travel (15,9\%) és a Pannon-Urlaub (16,5\%) bírt. A cégekről elmondható, hogy működésük átlagos időtartama 6,5 év volt, többségük sorsa végelszámolásba vagy felszámolásba torkollott (leghosszabb ideig - 1996-2009 között - a Berg-Hoff Kft. működött). A szervező cégek bejegyzett fö tevékenységi köre sokkal inkább a kiskereskedelem (különösen az egyéb nem bolti kiskereskedelem), mintsem az utazásszerve-

1. ábra: Ugyanazon postacímen működő termékbemutatós cégek Sales show companies operating at the same postal address

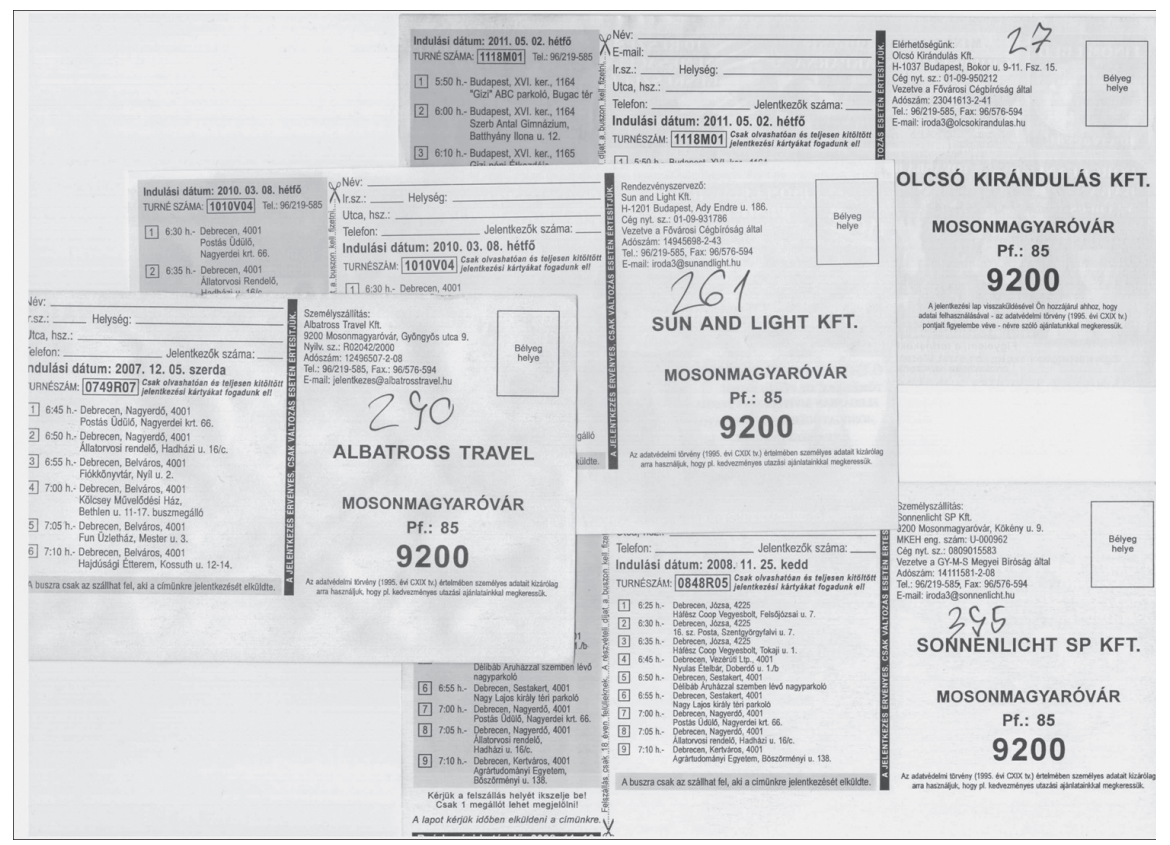


zés (ilyenkor egy regisztrált utazásszervező áll a kirándulás lebonyolításának hátterében), de olyan esetek is előfordultak, amikor kifejezetten utazásszervezők hirdettek termékbemutatós utakat (pl. Huber Reisen, Cathedrális Tours, ElVisz Travel, Medizon Utazási Iroda). Az egyik cég azt a megoldást választotta, hogy bejegyeztetett egy saját utazási irodát, így szorosabbra füzte a termékértékesítés és az utazásszervezés kapcsolatát: előbbi az An-za-dur Kft., utóbbi az An-za-tour Utazási Iroda nevet kapta.

A cédulákból ritkán derült fény arra, hogy mely cég mely árucikkeit értékesítik a termékbemutatón. Néhány esetben azonban magukon a reklámajándékok fényképein látható logóból (pl. Ex Natura - Pro Sana) vagy az ajándékokat felajánló cég nevéből (pl. MedicinArts Hungary) következtetni lehetett a bemutató tematikájára (pl. egészséggel kapcsolatos termékértékesítés), de sokkal inkább a zsákbamacska-effektus a jellemző.

\section{A célközönség}

Annak ellenére, hogy az utazással párosuló termékbemutatókról az idősebb korosztály érintettsége tükröződik a köztudatban, a reklámcédulákról különösebb korspecifikus megkülönböztetés nem olvasható ki. Minden cédula - feltehetően kötelező - eleme az arra vonatkozó tájékoztatás, hogy az utazásokon csak 18 év feletti személyek vehetnek részt, akik nagykorúságuknál fogva felelős döntést hozhatnak a termékbemutatón kínált árucikkek megvásárlásáról. Elvétve találkozhatunk olyan cédulákkal, ahol kifejezetten idős hölgyek vagy házaspárok fényképe utalna arra, hogy a szervezők a szépkorúakat tekintenék a kirándulások elsődleges célközönségének (ugyanakkor a szabadidős program vagy a garantált ajándékok sajátosságai már sokkal inkább sugalmazzák a tapasztaltabb generáció megszólítását - erre a későbbiekben visszatérünk).

\section{A célterület tér-és idóbeli dimenziói}

Az általunk megvizsgált reklámcédulák minden esetben egynapos kirándulásokra invitáltak, amelyek kivétel nélkül hétköznapokra estek. Különösebb szezonalitás nem volt kimutatható, az év minden hónapjában szerveztek utazással párosuló termékbemutatókat. Az ajánlatok 75\%-a bel-, 25\%-a külföldi utazást kínált.

Külföldi utazásokra elsősorban Budapestről kerülhetett sor, a fővárosból Ausztriába és Szlovákiába indultak utak, Gyöngyösről Szlovákiába, Debrecenből Romániába lehetett utazni (2. ábra). A külföldre irányuló utak esetében a kiindulási és a célállomás közötti átlagos távolság $145 \mathrm{~km}$ volt (2. ábra), a legrövidebb út (Debrecen-Nagyvárad) 73 km, a leghosszabb (Budapest-Felsőörs) 269 $\mathrm{km}$ volt. A legnépszerűbb határon túli célpontok között Ipolyszakállost, Pozsonyt, Köpcsényt és Nagyváradot lehet megemlíteni. A külföldi ajánlatok 77\%-ában a 

International destinations of sales show trips

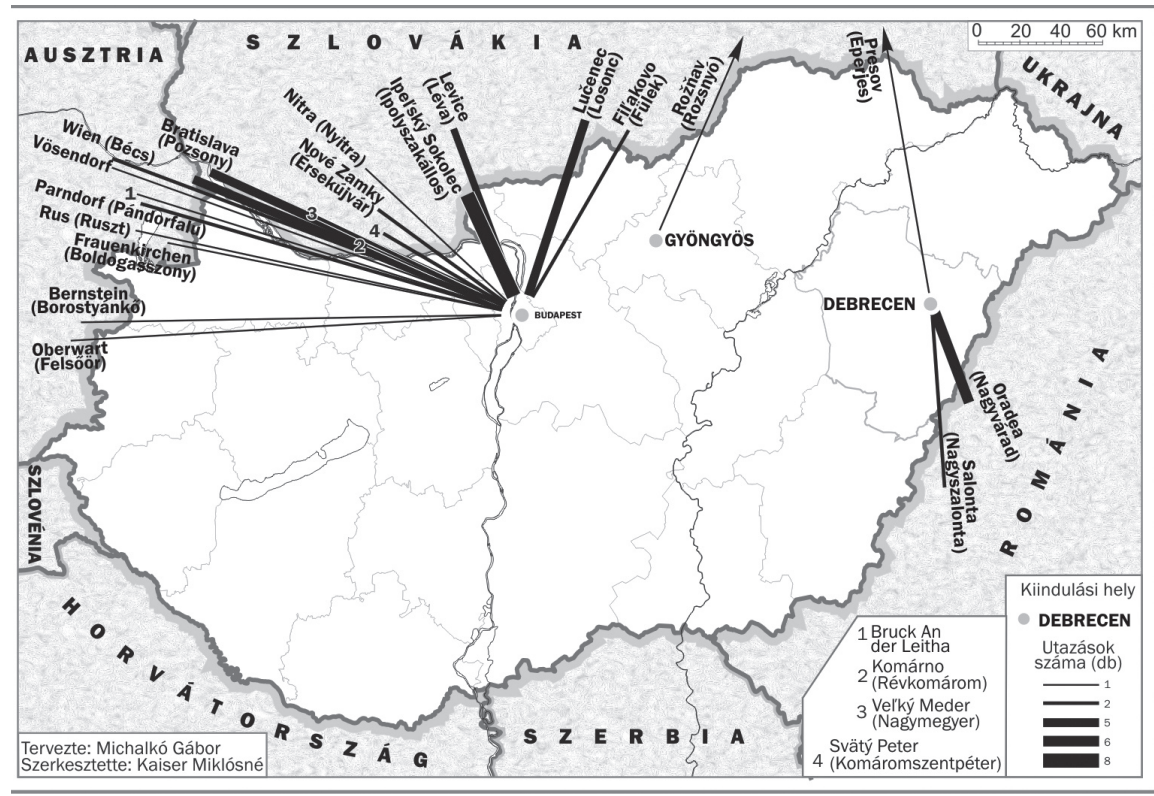

cédulán megjelenítik a célország zászlaját, hogy ezzel is hangsúlyozzák az utazás nemzetközi jellegét, amit azzal is kidomborítanak, hogy a felkeresendő település nevét nem magyarul, hanem az adott ország nyelvén tüntetik fel. Mindezt a cégek azzal tetézik, hogy a cédulán az Európai Unió kék alapon sárga csillagos logójával a háttérben felhívják a potenciális utazók figyelmét: „Érvényes személyi igazolvánnyal átlépheti a határt!". Az utazási ajánlatok földrajzi dimenziói meglehetősen hamisak, miközben egy határ közeli település a kirándulás célpontja, addig a cédulán olyan hangzatos marketingüzenetek olvashatók, mint például: „Barangoljon velünk Európában!” vagy „Fedezze fel Ausztriát!”.

A belföldi utazások földrajzi hatóköre viszonylag limitált, a kiindulási és a célállomás közötti átlagos távolság $112 \mathrm{~km}$ volt, a Budapestről induló utaknál ennél valamivel magasabb (134 km), Gyöngyös esetében $(98 \mathrm{~km})$ alacsonyabb volt az átlag, a Debrecenből induló utak $(103 \mathrm{~km})$ nem lépték át a Duna vonalát (3. ábra). Belföldi relációban a legrövidebb út (Debrecen-Hajdúszoboszló) $22 \mathrm{~km}$, a leghosszabb (Debrecen-Kiskunmajsa) $226 \mathrm{~km}$ volt. A három kiindulópontról összesen 90 magyarországi településre hirdettek kirándulásokat, ami változatos kínálatot tükröz (mindössze két esetben nem lehetett a célterületet települési szinten azonosítani: Fertő tó, Mezőföld). Az ajánlatok száma alapján a legnépszerűbb helyszínek közé Eger (20) Mezőkövesd (13), Egerszalók (12), Miskolc (11), Berekfürdő (7), Kiskunmajsa (7), Tiszakécske (7), Máriapócs (6) és Tiszaörs (6) sorolható. Öt olyan településsel találkoztunk, amely mindhárom helyszín ajánlatában megtalálható volt: Eger (20), Bogács (5), 
3. ábra: A belföldre irányuló termékbemutatós utak célterületei

Budapestről, Debrecenből és Gyöngyösről

Domestic destinations of sales show trips originating from Budapest, Debrecen and Gyöngyös
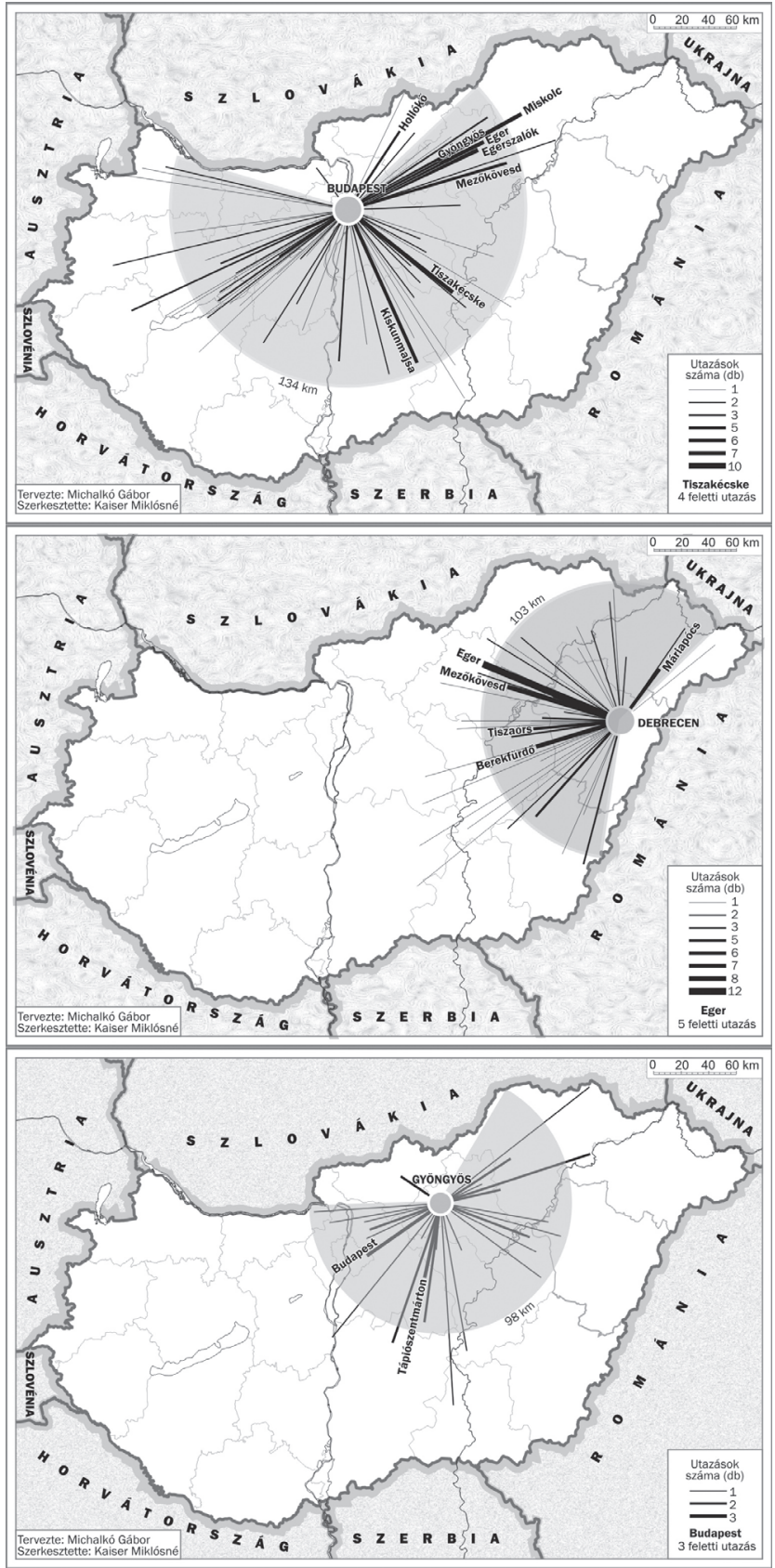
Nagykőrös (5), Cserkeszőlő (4) és Jászapáti (4). A legnépszerűbb célterületek általános turisztikai kínálatát értékelve megállapítható, hogy mindegyik településen müködik termál- vagy strandfürdő, többségük gyógyfürdő-minősítéssel is rendelkezik, így alkalmas az idősebb korosztály szabadidős igényeinek kielégítésére.

Az utazással párosuló termékbemutatók ajánlatainak földrajzi dimenzióját tovább erősíti az a tény, hogy a cédulák többsége stilizált térképet is tartalmaz, amelyen többé-kevésbé a valós fekvésnek megfelelöen tüntetik fel a célállomást. A szervezők által feltételezett földrajzi ismeretekből fakadóan a külföldi utak (82\%) esetében nagyobb, a belföldieknél (41\%) kisebb arányban találkozhatunk térképpel. A szervezők az ajánlatok földrajzi vonatkozásainak hangsúlyozásával a turizmus egyik alapköve, a környezetváltozás lehetőségére kívánják a célközönség figyelmét felhívni. Ezzel a kínálat turisztikai jellege kerül előtérbe, és háttérben marad, hogy mindezért cserébe egy termékbemutatón kell részt venni (a cédulák 96\%-án az „apró betűs” részben olvasható a termékbemutató ténye).

\section{A szabadidős program}

A célállomások nevének reklámcédulákon történő feltüntetése önmagában is képes az érdeklődés felkeltésére, mivel az érintett települések többsége jól csengő brand a hazai és a határ menti turisztikai kínálat palettáján (Sulyok 2006). A települések neve gyakran olyan asszociációkat kelt, amelyek az ott végezhető népszerű szabadidős tevékenységekre emlékeztetik a potenciális utazót. A szervezők azonban az utazási vágy fokozása és a kínálat elemeinek pontosítása végett a cédulákon néhány soros leírást adnak az általuk kínált szabadidős programról.

1. táblázat: A termékbemutatókhoz kapcsolódó szabadidős programok (\%) Leisure programmes included in the sales show trips (\%)

\begin{tabular}{lcc}
\hline \multicolumn{1}{c}{ Program } & Belföldi & Külföldi \\
\hline Fürdőzés, strandolás & 40,9 & 5,4 \\
Gasztronómia & 15,4 & 3,6 \\
Kulturális létesítmény meglátogatása (múzeum, vár) & 14,3 & 32,1 \\
Városnézés & 9,0 & 46,4 \\
Természetjárás & 9,0 & 1,8 \\
Szent hely felkeresése, ezotéria & 8,2 & 1,8 \\
Természetvédelmi terület, állatkert & 5,0 & 0 \\
Hajókázás, csónakázás & 4,3 & 0 \\
Vásárlás & 4,3 & 25,0 \\
Folklórműsor & 3,9 & 0 \\
\hline
\end{tabular}

Megjegyzés: előfordult, hogy egy cédulán több program is szerepelt. 
A cédulákon szereplő kínálatot vizsgálva jelentős eltérések észlelhetők a belföldi és a külföldi szabadidős programok között (1. táblázat). Míg a belföldi kirándulásokon a fürdőzés és a strandolás $(40,9 \%)$ a vezető program, addig a határon túli utazások során a városnézés $(46,4 \%)$ az első számú vonzerő. Ennek háttere meglehetősen összetett, egyik eleme feltehetően a kereslet összetételében, a másik az árképzésben húzódik. Ha a fürdőzés és a strandolás a megcélzott piaci szegmens, az idősebb korosztály körében népszerü, döntően ismert és közkedvelt hazai fürdővárosokba vezet az út, akkor az érintettek képesek megfizetni a fürdőbelépőt (egészségi állapotuknál fogva más utazások keretében is járnak gyógyfürdőbe, a szervezőktől olykor kedvezményt is kapnak). A határon túl - különösen Ausztriában - az utazók által igénybe veendő szolgáltatások már magasabb árszínvonalon érhetők el (euróval kell fizetni), ott önmagában a puszta városnézés, az átmeneti külföldön lét élménye is értékesíthető vonzerőt képvisel. A gasztronómia, vagyis táji ételspecialitások, borok, égetett szeszek megkóstolása egyrészt a bizalmat sugárzó ismertség, másrészt az ár-érték arány miatt leginkább belföldön ajánlható ki $(15,4 \%)$, a külföldi utak esetében nem jellemző (3,6\%). Jelentős az eltérés a vásárlás vonatkozásában is, ez a program a határon túli utakon gyakoribb (25,0\%), belföldön alig jelenik meg (4,3\%). A vásárlás valamely termelővállalat mintaboltjában történik, a cédulák kínálata alapján az Ipolyszakálloson (Szlovákia) található Natur Products - Németh s.r.o. mézüzem és a Kittseeben (Ausztria) működő Hauswirth csokoládégyár meglátogatását találják a szervezők vonzó programnak. A különböző kulturális létesítmények, várak, múzeumok, kiállítások stb. felkeresése bel- (14,3\%) és külföldön $(32,1 \%)$ egyaránt dobogós kínálati elemet képvisel. Ugyanazon a helyszínen, ugyanazon szervező által kínált program bizonyos időközönként megújul, így egész évben változatos utazási élmény részesei lehetnek a termékbemutatók végigülésére vállalkozók.

\section{A szolgáltatások}

Tekintettel arra, hogy a szervezők az utazással párosuló termékbemutatók turisztikai arculatát igyekeznek minél erőteljesebben hangsúlyozni, az egynapos kirándulásokat a tradicionális társasutakhoz illő szolgáltatáscsomagban kínálják. A csomag alapvető eleme az oda-vissza út, amelyhez a cédulák információi alapján kényelmes autóbusz áll a rendelkezésre. Ahogy már említettük, a „turizmus leple alatt" tartott termékbemutató is az út kötelező tartozéka, számos cédulán megjelenik, hogy erre a délelőtti órákban kerül sor. Az ebéd különösen vonzó elemét képviseli a vizsgált kirándulásoknak, olyannyira, hogy a cédulák nagyobbik részében (55\%) egy tányér ínycsiklandozó frissensült vagy készétel fényképét is feltüntetik. Az ebédet követően szabadidős program következik, az erre való invitáláshoz a cédulák 90\%-ában az adott helyszínhez és tevékenység- 
hez kötődő zsánerképet alkalmaznak (pl. boldogan gyógyfürdőzők vagy a mintaboltban megvásárolható húsvéti csokoládényuszik). A termékbemutató köré épülő turisztikai szolgáltatások csomagban történő értékesítését nagymértékben elősegítik a garantált reklámajándékok, amelyeket a cédulákról tükröződő kínálat $74 \%$-a tartalmaz. A cédulák felületének tekintélyes részét elfoglaló, hivalkodóan előtérbe állított ajándéktárgyak nagyobbik része a konyhafelszerelések kategóriájába sorolható (64,1\%), jelentős a kisebb műszaki cikkek (41,7\%) és a dísztárgyak (20,5\%) szerepeltetése. Ezen túlmenően háztartási vegyi árukkal, kozmetikumokkal, a legkülönbözőbb lakásfelszerelési cikkekkel, nemegyszer élelmiszerek ajándékozásával ösztönzik részvételre az érdeklődőket. Egyes reklámajándékok (pl. plüssfigura) esetében külön felhívják a célközönség figyelmét arra, hogy az adott tárgy akár az unokáknak is továbbajándékozható. Figyelemre méltó a cédulákon megjelenő árukapcsolás, az esetek 10\%-ában találkozhatunk többnapos, külföldre szóló, termékbemutatót is magukba foglaló utazási ajánlatokkal.

\section{Az ár}

Az utazással párosuló termékbemutatók egyik legkarakterisztikusabb jellemvonása az ár, vagyis a rendkívül kedvező részvételi díj. A szervezők a reklámcédulákon kivétel nélkül megjelenített árral azt kívánják a potenciális kereslet számára sugallni, hogy „ennyiért a bolondnak is megéri elutazni”. Figyelmen kívül hagyva azt a momentumot, hogy a magyar állampolgárok a legkülönbözőbb kedvezményekkel vehetik igénybe a helyi és a helyközi autóbuszjáratokat belföldön, a termékbemutatós utak részvételi díja jócskán alatta marad a hasonló távolságot megtevő Volán-járatok teljes árú jegyének.

A cédulákon szereplő részvételi díjak átlaga 1260 Ft (a legolcsóbb $200 \mathrm{Ft}$, a legdrágább 1590 Ft), nincs érdemi különbség a belföldi vagy a határon túlra tar-

\begin{tabular}{lcc}
\multicolumn{3}{c}{$\begin{array}{c}\text { 2. táblázat: Az utazások árképzése } \\
\text { Pricing characteristics of the trips }\end{array}$} \\
\hline \multicolumn{1}{c}{ Megnevezés } & Belföldi & Külföldi \\
\hline Teljes ár (Ft) & 1260 & 1240 \\
\hline Ebéd (\%) & & \\
$\quad$ Benne van az árban & 49,3 & 28,1 \\
Kedvezményt ad & 30,6 & 28,1 \\
Külön fizetendő & 20,1 & 43,8 \\
\hline Szabadidős program (\%) & & \\
Benne van az árban & 50,4 & 50,0 \\
Kedvezményt ad & 23,8 & 2,0 \\
Külön fizetendő & 11,4 & 4,0 \\
Nem releváns & 14,4 & 44,0 \\
\hline
\end{tabular}


tó kirándulások árai között (2. táblázat). Az ajánlatok 20\%-a úgynevezett akciós árat tartalmazott, az átlagos árkedvezmény 7\%-os volt. Az utazási költségek egyértelműen a részvételi díj részét képezték, azonban az ár az ebédet és a szabadidős programot már nem minden esetben foglalta magába. A belföldi utazási ajánlatok fele $(49,3 \%)$ az ebédet a részvételi díj részeként jeleníti meg, a külföldre irányulók esetében $(28,1 \%)$ már nem ilyen nagyvonalúak a szervezők; részben a határon túli magasabb árfekvésű vendéglátó-ipari kínálattal hozható összefüggésbe, hogy az osztrák, szlovák és román utak 43,8\%-ában külön kell az ebédért fizetni. (Az árubemutatókra jellemző módon hétköznap kerül sor, amikor a vidéki térségek ürességtől kongó éttermeiben nyomott áron lehet helyiséget bérelni és ebédet rendelni). A szabadidős program az ebédhez hasonlóan az esetek mintegy felében fakultatív, ebben a bel- és külföldi utak között nincs eltérés, azonban míg a belföldi úti célok 23,8\%-ában kedvezményesen lehet egyes turisztikai létesítmények szolgáltatásait igénybe venni, addig a külföldi utazásokon sokkal inkább a nem fizetős programok, különösképpen a városnézések jellemzőek (44,0\%). A reklámcédulákon szereplő ajánlatokat együttesen vizsgálva megállapítható, hogy a részvételi díj legtöbb esetben gasztronómiai (27,8\%), kulturális létesítményeket (22,2\%) és szent helyeket (14,6\%) felkereső programokat tartalmaz (fürdőbelépőt viszont mindössze az esetek 6,9\%-ban). Ha abból indulunk ki, hogy egy autóbusz bérleti díja a termékbemutatós utazások átlagos távolságával számolva $(112 \mathrm{~km} \times 2 \times 300 \mathrm{Ft})=70$ ezer Ft körül van, akkor a 40 fös utazóközönség részvételi díjából számolt $(40 \times 1260 \mathrm{Ft})=50$ ezer Ft körüli bevétel még az oda-vissza út költségeit sem fedezi (nem beszélve az ajándékokról, az ebédről, a szabadidős programról, az alkalmazottakról, a hirdetésről stb.), így a különbözetet feltehetően a termékbemutatón értékesített árucikkek árrése fedezi.

\section{Következtetések}

Ugyan a KSH nem gyüjt adatokat az egynapos belföldi utazásokról, a hazánk turizmusmarketingjével foglalkozó szervezet (Magyar Turizmus Zrt.) a M.Á.S.T. Piac- és Közvéleménykutató Társasággal együttműködésben kétévente felméri a magyar lakosság utazási szokásait, amelyből kirajzolódnak a határainkon belül zajló kirándulóforgalom fontosabb jellemvonásai. Megtudhatjuk például, hogy míg 2006-ban az összes egynapos belföldi utazáson belül 36,5\%-os volt a vásárlási motivációval útra kelők aránya, addig ez a mutató 2010-ben már 42,3\% volt (M.Á.S.T. 2007; neta.itthon.hu 2013). Nem tudjuk, hogy mennyi ebből a kiskereskedelmi egységeket, különösen a nagyvárosok hiper- és szupermarketjeit, diszkontáruházait, bevásárlóközpontjait felkeresők, valamint mennyi az utazással párosuló termékbemutatón résztvevők aránya, de az kiolvasható belőle, 
hogy a magyar lakosság előszeretettel köti össze az utazást a vásárlással. Ennek egyrészt a szocializmusra visszanyúló történelmi gyökerei vannak, amelyek a hiánygazdaságból fakadó áruéhségből táplálkoztak, másrészt a vásárlás szabadidős programként, szórakoztató tevékenységként történő értelmezése képezi alapját. Az utazással párosuló termékbemutatókat szervező cégek a reklámcédulákból kiolvasható üzenetek alapján azt a piaci szegmenst kívánják megcélozni, amelynek tagjai:

- az 1970-es, 1980-as évek csehszlovák „cipőtúráit” jó emlékként őrzik a fejükben, nem idegenkednek a lakókörnyezetükön kívüli vásárlásoktól;

- egykoron szerettek vállalati kirándulásokon, autóbuszos társasutakon részt venni és most sem zavarja őket, ha másokkal összezárva, kötött programokon vesznek részt;

- nemigen engedhetik meg maguknak, hogy turistaként utazzanak, ezért egy feltűnően alacsony árú, kifejezetten a szürke hétköznapokból való kimozdulásra ösztönző ajánlat felkeltheti az érdeklődésüket.

A fentiek alapján az idősebb, leginkább nyugdíjas státuszban lévő korosztály azonosítható a termékbemutatós utak első számú célcsoportjaként, amely számára a szervezők megteremtik a környezetváltozás, az élményszerű vásárlás lehetőségét, amelynek társaságot, értékesnek tűnő ajándéktárgyakat, hasznos szabadidő-eltöltést kínálnak. Mindezért cserébe elvárják tőlük, hogy fegyelmezetten végigüljék a termékbemutatót és vásárlásaikkal tegyék rentábilissá az áron alul kínált utazást. Mivel az utazások szervezőinek a kiskereskedelem képezi a fó tevékenységét, cégük profilját az árucikkek nem bolti értékesítése adja, így a turizmusként értelmezhető utazás, ebéd, szabadidős program hármasságát kizárólag a termékbemutatón való részvétel ösztönzésére kínálják fel. A környezetváltozással csupán azt az illúziót kívánják kelteni, mintha valóban egy tradicionális turistaútról lenne szó, amelyen a mindennapokhoz képest „illik” nagyvonalúbban viselkedni, ahol nem szokás garasoskodni, ahol a társasúton résztvevők felé is meg kell felelni, példát kell mutatni (ez esetben a vásárlással), nehogy megszólják az embert az ismerősei.

Az utazás ára és a részvételért cserébe hazavihető grátisz termékek egymást erősítve azt sugallják, hogy a reklámcédulákon szereplő ajánlat valójában egy kedves ajándék, amiért cserébe elvárható a bemutatón szereplő árucikkek megvásárlása. Az egész utazás hamis életérzést gerjeszt, amelynek a szervezők a vámszedői. Az utas, ha esetleg sejti is, hogy itt a megtévesztése zajlik, ami elől el kellene zárkóznia, a megfelelési kényszer mégis ráveszi őt a vásárlásra. A határon túli kirándulások még inkább ráerősítenek erre, hisz az idősebb korosztály életében a külföldi utazás felértékelődik, a rendszerváltozás előtt külföldre menni komoly kiváltság volt, így ezzel az asszociációval élhetnek a szervezők a vásárlásra való rábeszélés során.

Annak ellenére, hogy a felkeresett célterületek a termékértékesítés folyamatának díszletei és az utazás egy „pszeudoturisztikai élmény”, a termékbemutatós utak mégis elősegítik a Kárpát-medence megismerését, a belföldi turizmus, 
de különösen a szolgáltatásokat nyújtó vállalkozások és szabadidős létesítmények forgalmának élénkítését. Az üzleti funkció mellett hangsúlyozni kell azt is, hogy - feltehetően a szervezők szándékán kívül - az ilyen kirándulások sajátos szociálturisztikai feladatot is ellátnak: utazási és közösségi élményt biztosítanak a kispénzű, leginkább nyugdíjas korosztály számára.

\section{Köszönetnyilvánítás}

A tanulmány alapjául szolgáló kutatást az OTKA (K 100953) támogatta. A szerzők e helyen szeretnének köszönetet mondani Bujdosó Zoltánnak (Károly Róbert Főiskola) és Kozma Gábornak (Debreceni Egyetem) a reklámcédulák gyűjtésében való aktív közreműködésükért, valamint Farkas Jácintnak (MTA CSFK Földrajztudományi Intézet) a cédulákon szereplő információk számítógépes rögzítéséért.

\section{Jegyzetek}

1 Az Amway magyarországi leányvállalata 1991-ben jött létre, alapvetően kozmetikumok és háztartási vegyi áru értékesítésével foglalkozott.

2 213/1996. (XII. 23.) kormányrendelet az utazásszervező és -közvetítő tevékenységről.

\section{Irodalom}

Anderson, F., Littrel A. (1995): Souvenir-purchase behaviour of women tourists. Annals of Tourism Research, 2., 328-348.

Babbie, E. (1999): A társadalomtudományi kutatás gyakorlata. Balassi Kiadó, Budapest

Coles, T. (2004): Tourism and retail transactions: lessons from the Porsche experience. Journal of Vacation Marketing, 4., 378-389.

Czirfusz M. (2010): A földrajztudományi mező müködése a hatvanas évek két kandidátusi védése alapján. In: Bajmócy P., Józsa K. (szerk.): Geográfus Doktoranduszok X. Országos Konferenciája. SZTE TTIK, Szeged (CD)

Darden, W., Lennon, J., Darden, D. (1978): Communicating with interurban shoppers. Journal of Retailing, 1., 51-64.

Dessewffy T. (1998): Nyerészkedők és utazók: a turista politikai konstrukciója a Kádár-rendszerben. Kritika, 10., 32-35.

Di Matteo, L., Di Matteo, R. (1996): An analysis of Canadian cross-border travel. Annals of Tourism Research, 1., 103-122.

Freathy, P., O'Connell, F. (1999): A typology of European airport retailing. The Service Industries Journal, 3., 119-134.

Gordon, B. (1986): The souvenir: messenger of the extraordinary. Journal of Popular Culture, 3., 135-146.

Hajdú P. (2012): Buszos vásárlás: óva intenek. Magyar Nemzet, június 19.

Hankiss E. (1989): Kelet-európai alternatívák. Fehéren-feketén. Közgazdasági és Jogi Kiadó, Budapest 
Heung, C., Qu, H. (1998): Tourism shopping and its contributions to Hong Kong. Tourism Management, 4., 383-386.

Hobson, J. (1996): Leisure shopping and tourism: the case of the South Korean market to Australia. Turizam, 9-10., 228-244.

Hunyadi M. (2011): „HelySzínre” vitt turisták. A termékbemutató-turizmus élményvilága. In: Fejős Z. (szerk.): Színre vitt helyek. Néprajzi Múzeum, Budapest, 82-99. (Tabula könyvek; 11.)

Jansen-Verbeke, M. (1991): Leisure shopping: a magic concept for the tourism industry. Tourism Management, 1., 9-14.

Jenssen, W. (1966): Sales effects of TV, radio, and print advertising. Journal of Advertising Research, 2., $2-7$.

Kolosi T (1984): A társadalmi szerkezet változása Magyarországon 1-2. In: Hanák G. (szerk.): Gólyavári esték - előadások a magyar történelemról. RTV Minerva, Budapest, 197-220.

Kornai J. (1994): A hiánygazdaság felszámolása: általános elemzés és a magyar fejlődés vizsgálata. Közgazdasági Szemle, 7-8., 569-605.

Kun A., Boros L., Pál V. (2009): A tartalomelemzés lehetőségei a településföldrajzban: Esztergom és Tatabánya vetélkedése a sajtó tükrében. In: Csapó T., Kocsis Zs. (szerk.): A közép- és nagyvárosok településföldrajza. Savaria University Press, Szombathely, 308-321.

Littrel, A. (1990): Symbolic significance of textile crafts for tourists. Annals of Tourism Research, 2., $228-245$.

Littrel, A. (1994): Souvenirs and tourism styles. Journal of Travel Research, 1., 3-11.

M.Á.S.T. (2007): A magyar lakosság utazási szokásai. Turizmus Bulletin, 1-2., 12-27.

Malloy, D., Fennell, D. (1998): Codes of ethics and tourism: an exploratory content analysis. Tourism Management, 5., 453-461.

Marx, K. (1955): A tóke. A politikai gazdaságtan bírálata. Szikra, Budapest

McBoyle, G. (1996): Green tourism and Scottish distilleries. Tourism Management, 4., 255-263.

Michalkó, G. (2000): Relationship between the Yugoslavian tourism and retail turnover in Hungary. Turizam, 4., 131-133.

Michalkó, G., Colombino, A., Minca, C. (2005): Il turismo da shopping frontaliero: un confronto tra Lenti (Ungheria) e Trieste (Italia). Turistica, 2., 81-100.

Michalkó, G., Timothy, D. (2001): Cross-border shopping in Hungary: causes and effects. Visions in Leisure and Business, 1., 4-22.

Michalkó, G., Váradi, Zs. (2004): Croatian shopping tourism in Hungary: the case study of Barcs. Tourism, 4., 351-359.

Michalkó G. (2004): Bevásárlóturizmus. Kodolányi János Főiskola, Székesfehérvár

Murphy, L., Moscardo, G., Benckendorff, P., Pearce, P. (2011): Evaluating tourist satisfaction with the retail experience in a typical tourist shopping village. Journal of Retailing and Consumer Services, 4., 302-310.

Murphy, L., Benckendorff, P., Moscardo, G., Pearce, P. (2012): Tourist shopping villages. Forms and functions. Routledge, London

Nagy E. (2000): Globális stratégiák és lokális válaszok a kiskereskedelemben. In: Horváth Gy., Rechnitzer J. (szerk.): Magyarország területi szerkezete és folyamatai az ezredfordulón. MTA RKK, Pécs, 354-373.

Nemzeti Fogyasztóvédelmi Hatóság (2011): Összefoglalójelentés az árubemutatóval egybekötött termékértékesítési tevékenység ellenörzéséról. Nemzeti Fogyasztóvédelmi Hatóság, Budapest. http://www.nfh.hu/data/cms115718/Az_arubemutatoval_egybekotott_termekertekesitesi_tevekenyseg_ellenorzeserol.pdf (Letöltés: 2013. március 25.)

Nickerson, P. (1995): Tourism and gambling content analysis. Annals of Tourism Research. 1., 53-66.

Nordfalt, J., Lange, F. (2013): In-store demonstrations as a promotion tool. Journal of Retailing and Consumer Services, 1., 20-25.

Phillips, R., Steiner, C. (eds.) (1999): Unpacking culture: Art and commodity in colonial and postcolonial worlds. University of California Press, Los Angeles

S. Ráduly J. (2001): Kirándulós árubemutatók: áprilist járatók. HVG, 45. 122-123.

Sands, S., Oppewal, H., Beverland, M. (2009): The effects of in-store themed events on consumer store choice decisions. Journal of Retailing and Consumer Services, 5., 386-395. 
Shenhav-Keller, S (1993): The Israeli souvenir. Annals of Tourism Research, 2., 182-196.

Sikos T. T., Hoffmann I.-né (2004): A fogyasztás új katedrálisai. MTA Társadalomkutató Központ, Budapest

Sirakaya-Turk, E., Uysal, M., Hammit,W., Vaske, J. (2011): Research methods for leisure, recreation and tourism. CABI, Wallingford

Skumanich, S., Kintsfather, D. (1998): Individual media dependency relations within television shopping. Communication Research, 2., 200-219.

Stepchenkova, S. (2012): Content analysis. In: Dwyer, L., Gill, A., Seetaram, N. (eds.): Handbook of research methods in tourism. Quantitative and qualitative approaches. Edward Elgar, Cheltenham, 443-458.

Sulyok J. (2006): A turisztikai imázs. Turizmus Bulletin, 4., 55-62.

Timothy, D. (2005): Shopping tourism, retailing and leisure. Channel View Publications, Clevedon

Timothy, D. (1999): Cross-border shopping: tourism in the Canada-United States borderlands. Visions in Leisure and Business, 4., 4-18.

Timothy, D., Butler, R. (1995): Cross-border shopping: a North American perspective. Annals of Tourism Research, 5., 16-34.

Toops, S. (1993): Xinjiang's handicraft industry. Annals of Tourism Research, 1., 88-106.

Tömöri, M. (2011): The role of the "DebOra" cross-border Eurometropolis in the Hungarian-Romanian CBC relations: a case study of shopping tourism in Debrecen and Oradea. Eurolimes, 11. 170-178.

Walsh, G., Gwinner, K. (2009): Purchasing vacation packages through shop-at-home television programs: an analysis of consumers' consumption motives. Journal of Vacation Marketing, 2., 111-128.

Wessely A. (2000): Utazó emberek, utazó tárgyak. Replika, 39., 95-106.

Wong, I., Wan, Y. (2013): A systematic approach to scale development in tourist shopping satisfaction: linking destination attributes and shopping experience. Journal of Travel Research, 1., 29-41.

Zsom B. (2013): A hazai információs társadalom fejlesztési dokumentumainak vizsgálati lehetőségei tartalomelemzési módszerekkel. Földrajzi Közlemények, 1., 40-50.

http://fn.hir24.hu/itthon/2012/06/01/duborog-a-nyugdij-biznisz/ (Letöltés: 2013. április 2.)

http://neta.itthon.hu/szakmai-oldalak/magyar-lakossag-utazasai (Letöltés: 2013. április 15.)

http://pfiffige-senioren.de/kaffeefahrt.htm (Letöltés: 2013. április 5.) 